\title{
Optimization of Fluorometric Assay for Ozone in Solution
}

\author{
Hiromi Nagano, Gotaro Shiota, and Hidetoshi Arakawa \\ Department of Analytical Biochemistry, School of Pharmacy, Showa University, 1-5-8 Hatanodai, Shinagawa-ku, Tokyo 142-8555, Japan
}

Correspondence should be addressed to Hidetoshi Arakawa; arakawa@pharm.showa-u.ac.jp

Received 6 December 2013; Revised 6 February 2014; Accepted 6 February 2014; Published 24 March 2014

Academic Editor: Jesus Simal-Gandara

Copyright (C) 2014 Hiromi Nagano et al. This is an open access article distributed under the Creative Commons Attribution License, which permits unrestricted use, distribution, and reproduction in any medium, provided the original work is properly cited.

\begin{abstract}
Ozone is widely used for sterilization, deodorization, and cleaning. However, the effects of ozone on human are not well understood, because there is currently no reliable assay method for ozone. Therefore the accurate measurement of ozone is important for its safe use. Here, we report optimized conditions for use with fluorescein derivative $\mathbf{1}$ (probe $\mathbf{1}$ ). Under optimum conditions, probe $\mathbf{1}$ reacted with ozone quantitatively and specifically to generate a fluorescent substance with an excitation maximum at $493 \mathrm{~nm}$ and an emission maximum at $523 \mathrm{~nm}$. We conclude that this assay will be useful for quantifying ozone in solution.
\end{abstract}

\section{Introduction}

Ozone is used for sterilizing fingers, foods, and tap water for preventing nosocomial infection and deodorization. Recently, ozone has been used in cosmetics, for sterilization after dental treatment and for washing the skin around burns.

However, the effects of ozone on human are unknown, and there is currently no reliable method to evaluate its effects. Thus, prior to the application of ozone in medical care, a means for accurately measuring ozone is required.

Ozone is currently measured by the ultraviolet absorption [1], the iodine titration [2], the indigo dye [3,4], or the galvanic method [5]. However, these methods are not sensitive and specific for ozone.

The Koide group previously reported probe 1 and demonstrated proofs of concepts (Figure 1) [6]. However, the use of probe 1 was not specifically optimized for quantifying ozone in solution. Given the paucity of user-friendly, selective, and robust method for measuring ozone in solution, we set out to validate and optimize the fluorometric method with probe 1. We report herein the optimum conditions for measuring ozone using probe $\mathbf{1}$.

\section{Materials and Methods}

2.1. Reagents. Reagents were obtained from the following suppliers: hydrogen peroxide $30 \%$, iron (II) sulfate heptahydrate, $\mathrm{NaClO}$, and hypoxanthine that were from Wako
Pure Chemical Industries Ltd. (Osaka Japan). Xanthine oxidase was obtained from bovine milk and pyrrolidine from SIGMA-ALDRICH, Co (USA). Diethylenetriaminepentaacetic acid (DETAPAC) and NOC-7 were obtained from DOJIN MOLECULAR TECHNOLOGIES, INC. All other chemicals were obtained as reagent-grade.

Probe 1 was donated kindly from Professor K. Koide of University of Pittsburgh [6].

Ozone-containing water was prepared by the electrolysis of water (ozone generator: VMC JAPAN). The concentration of standard ozone-containing water was calculated from its absorbance at a wavelength of $254 \mathrm{~nm}$ using a molar absorptivity coefficient, $\varepsilon$, of $2950 \mathrm{~mol}^{-1} \mathrm{Lcm}^{-1}$ [7].

Preparation of probe 1 solution for assay: a solution of probe $1(12.5 \mu \mathrm{mol} / \mathrm{L})$ in a mixture of $5 \% \mathrm{v} / \mathrm{v}$ methanol in a $0.5 \mathrm{mmol} / \mathrm{L}$ phosphate buffer $(\mathrm{pH} 3.3)$ was prepared immediately prior to use.

2.2. Preparations of $\mathrm{OH}$ Radical, Superoxide, and Nitric Oxide. Conditions for generation of $\mathrm{OH}$ radical (the Fenton reaction): $0.5 \mathrm{mmol} / \mathrm{L}$ phosphate buffer $(\mathrm{pH} 7) 1600 \mu \mathrm{L}, 5 \times$ $10^{-4} \mathrm{~mol} / \mathrm{L} \mathrm{FeSO}_{4}$ solution $300 \mu \mathrm{L}, 1 \times 10^{-3} \mathrm{~mol} / \mathrm{L}$ DETAPAC $300 \mu \mathrm{L}, \mathrm{H}_{2} \mathrm{O} 500 \mu \mathrm{L}$, and $400 \mathrm{ppm} \mathrm{H}_{2} \mathrm{O}_{2} 300 \mu \mathrm{L}$ [8].

Conditions for generation of superoxide anion radical $\left(\bullet \mathrm{O}_{2}{ }^{-}\right): 40 \mathrm{ppm}$ hypoxanthine $90 \mu \mathrm{L}$ and $0.1 \mathrm{U} / \mathrm{mL}$ xanthine oxidase $10 \mu \mathrm{L}$ were mixed [9]. 
<smiles>C=CCCOc1cc2oc3cc(=O)c(Cl)cc-3c(-c3ccccc3CO)c2cc1Cl</smiles>

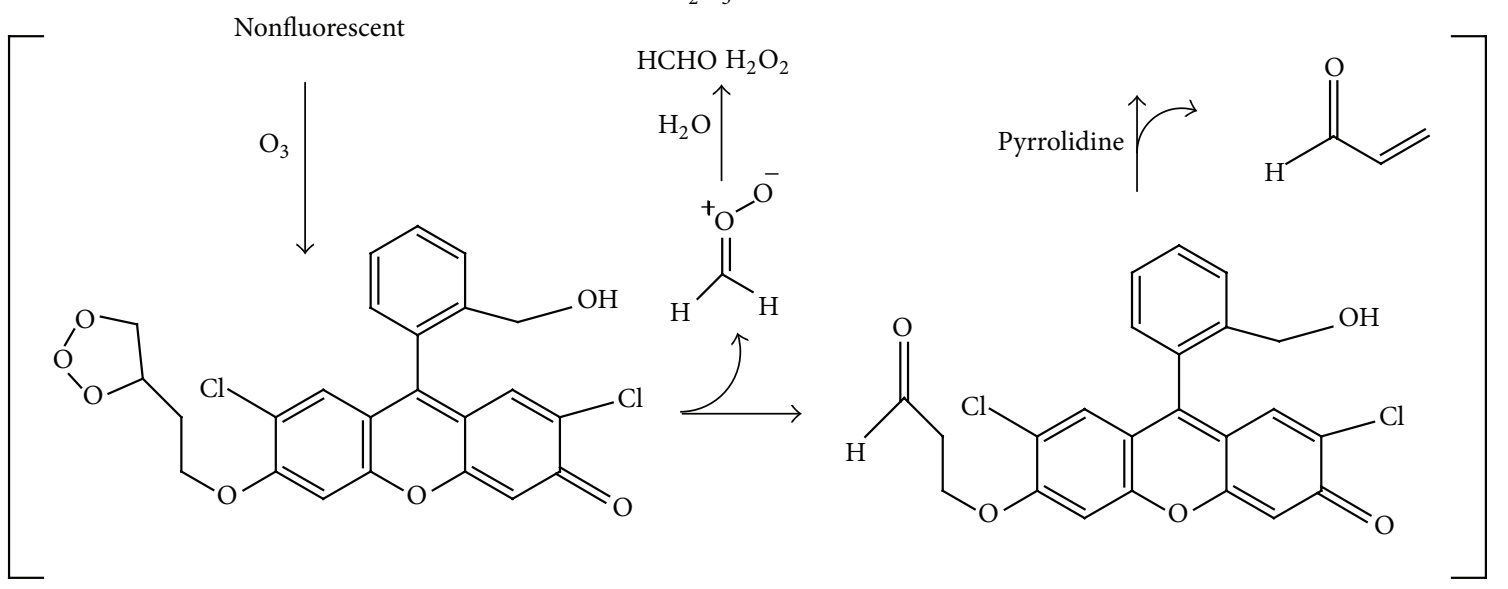

FIGURE 1: Reaction of probe 1 with ozone.

Condition for generation of nitric oxide (NO): $1 \mathrm{mg} / \mathrm{mL}$ NOC-7 $50 \mu \mathrm{L}$ was diluted with $\mathrm{H}_{2} \mathrm{O} 1200 \mu \mathrm{L}$ [10].

2.3. Method. Ozone was measured as follows. A sample of ozone-containing water $(100 \mu \mathrm{L})$ was added to the solution of probe $1(900 \mu \mathrm{L})$ and the resulting solution was incubated at $37^{\circ} \mathrm{C}$ for $1 \mathrm{~h}$. Then $50 \mathrm{mmol} / \mathrm{L}$ pyrrolidine solution $(100 \mu \mathrm{L})$ was added to complete the $\beta$-elimination in 5 minutes room temperature. Upon the completion of the elimination, the fluorescence intensity was measured (ex. $493 \mathrm{~nm}$, em. $523 \mathrm{~nm})$.

2.4. Apparatus. Spectrophotometer (JASCO V-530, JAPAN) for UV measurement of ozone concentration and spectrofluorometer (JASCO FP-6500, JAPAN) for measurement of fluorescence of probe 1 were used.

\section{Results and Discussion}

Specifically, we examined the effects of $\mathrm{pH}$, reaction time, and the probe concentration, to develop a highly sensitive and accurate method for measuring ozone.

First, the effects of the $\mathrm{pH}$ values of $5 \mathrm{mmol} / \mathrm{L}$ phosphate buffers on fluorescence intensity were studied. As shown in Figure 2, the fluorescence intensity and signal-to-noise (S/N) ratio increased as the $\mathrm{pH}$ decreased. As a result, we chose $\mathrm{pH} 3$ as the optimum $\mathrm{pH}$. Generally the decomposition of ozone in aqueous solution is catalyzed by $\mathrm{OH}^{-}$ions [11]. Therefore, the acidic condition stabilize ozone, and it promotes ozonolysis of probe 1 in the first step.

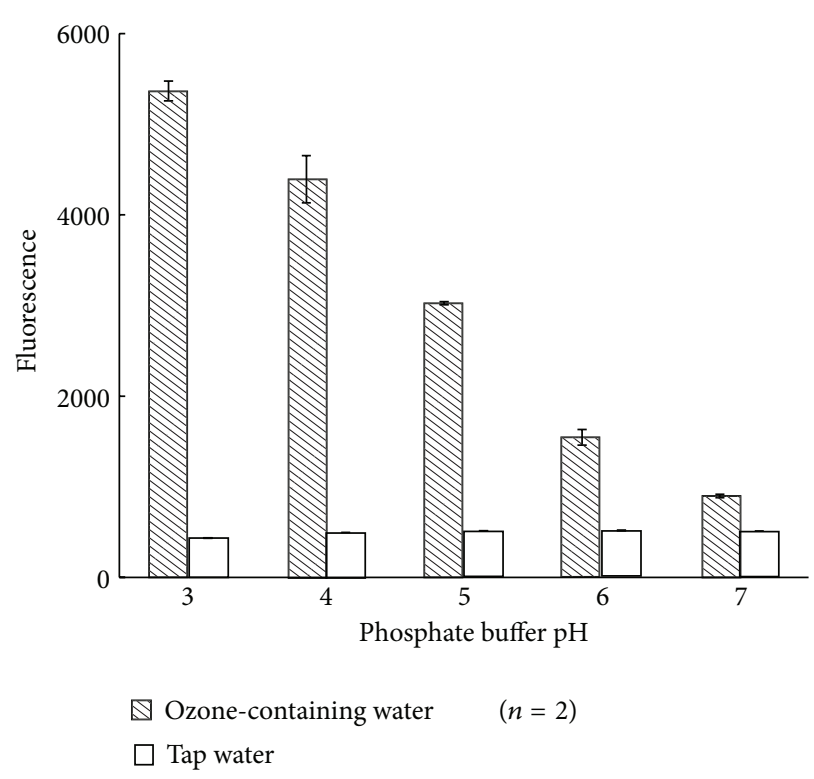

FIGURE 2: Effect of phosphate buffer $\mathrm{pH}$ on fluorescence intensity.

The effect of the salt concentration of the $\mathrm{pH} 3$ phosphate buffer on fluoremetric method was investigated. As shown in Figure 3, the fluorescence intensities and $\mathrm{S} / \mathrm{N}$ ratios increased as the concentrations of salt decreased. Therefore, we chose $0.5 \mathrm{mmol} / \mathrm{L}$ for the following experiments. 


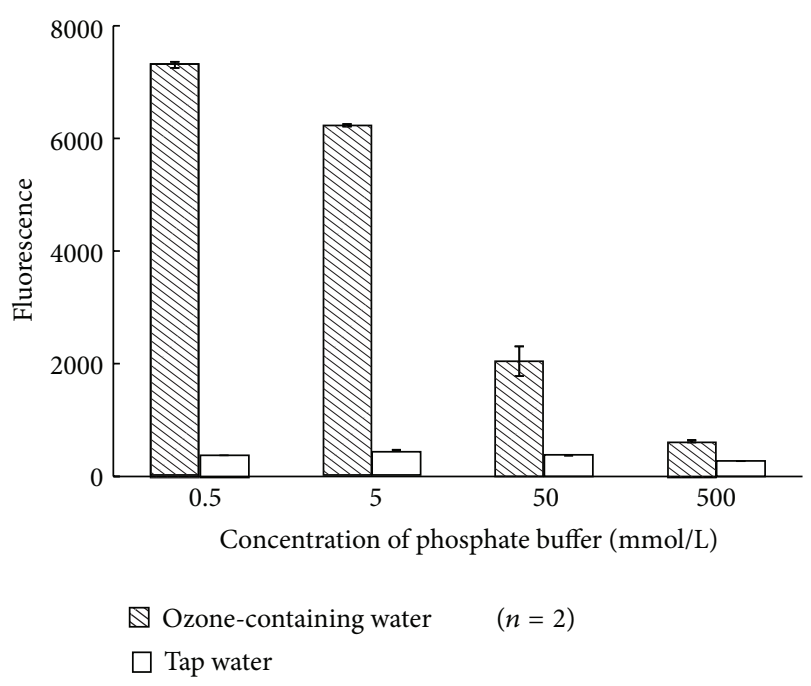

FIGURE 3: Effect of concentration of phosphate buffer on fluorescence intensity.

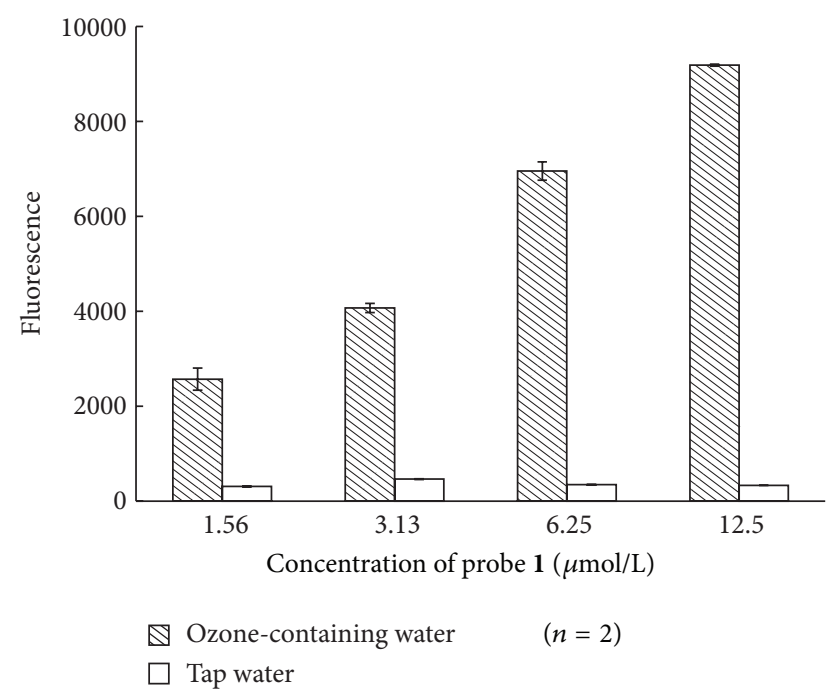

FIGURE 4: Effect of concentration of probe 1 on fluorescence intensity.

Next, probe 1 was examined at $1.56 \mu \mathrm{mol} / \mathrm{L}, 3.13 \mu \mathrm{mol} / \mathrm{L}$, $6.25 \mu \mathrm{mol} / \mathrm{L}$, and $12.5 \mu \mathrm{mol} / \mathrm{L}$ concentrations. The fluorescence intensity and $\mathrm{S} / \mathrm{N}$ ratio were the highest at $12.5 \mu \mathrm{mol} / \mathrm{L}$, as shown in Figure 4. Because the kinetics of alkene ozonolysis is first-order with respect to an alkene [6], this observation is consistent with the literature.

The concentration $(0-100 \mathrm{mmol} / \mathrm{L})$ of pyrrolidine solution used for catalysis was determined. The fluorescence intensity of ozone water increased as the concentration of the pyrrolidine solution increased, although a decrease was eventually observed: a decrease in the fluorescence intensity of ozone water was observed between 50 and $100 \mathrm{mmol} / \mathrm{L}$, and for the blank between 5 and $10 \mathrm{mmol} / \mathrm{L}$, as shown in Figure 5 . We chose $50 \mathrm{mmol} / \mathrm{L}$ as the optimum concentration

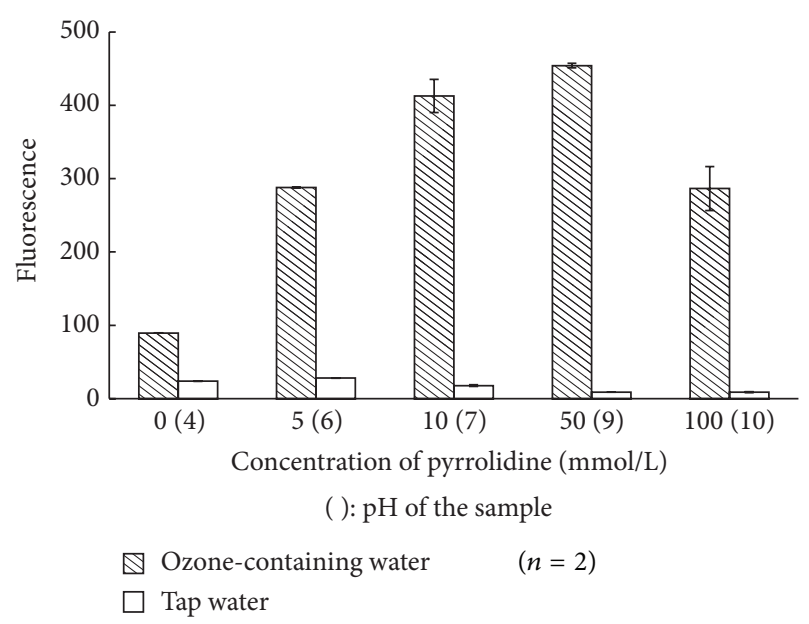

FIGURE 5: Effect of concentration of pyrrolidine on fluorescence intensity. (): $\mathrm{pH}$ for fluorometry.

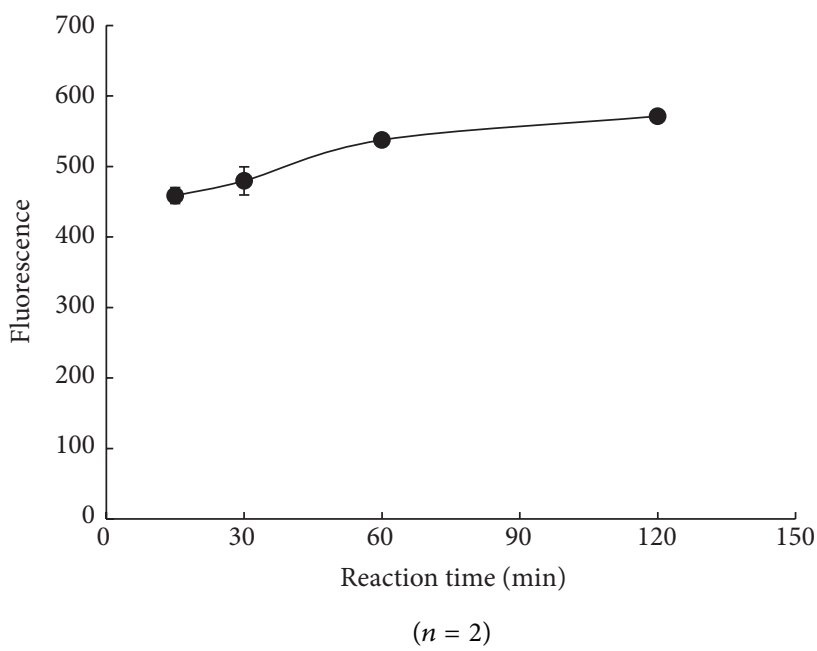

Figure 6: Effect of reaction time at $37^{\circ} \mathrm{C}$ on fluorescence intensity.

of pyrrolidine because this provided the strongest fluorescence intensity and largest $\mathrm{S} / \mathrm{N}$ ratio. The increase in the fluorescence intensity may arise from promotion of aldehyde $\beta$-elimination [12].

The reaction time $\left(15,30,60\right.$, or $120 \mathrm{~min}$ at $37^{\circ} \mathrm{C}$, or overnight $\left(120 \mathrm{~min}\right.$ at $37^{\circ} \mathrm{C}$, then $\left.4^{\circ} \mathrm{C}\right)$ ) was determined. The fluorescence intensity and $\mathrm{S} / \mathrm{N}$ ratio were strongest at $120 \mathrm{~min}$, but there was little difference between $60 \mathrm{~min}$ and $120 \mathrm{~min}$, as shown in Figure 6 . And the $\mathrm{S} / \mathrm{N}$ ratio decreased overnight (data not shown). Therefore, we chose $60 \mathrm{~min}$ as the optimum reaction time.

A standard curve for ozone water is shown in Figure 7. The limit of detection of ozone in water was $0.49 \mathrm{pmol}$ from blank + 3SD.

The reproducibility of this analysis was then investigated using tap water as the blank: $\mathrm{CV}=0.9 \%, n=7$; Ozonecontaining water $0.16 \mathrm{ppm}$ : $\mathrm{CV}=2.66 \%, n=7$; Ozonecontaining water $3.25 \mathrm{ppm}$ : $\mathrm{CV}=4.82 \%, n=7$. These data show satisfactory reproducibility of this assay. 


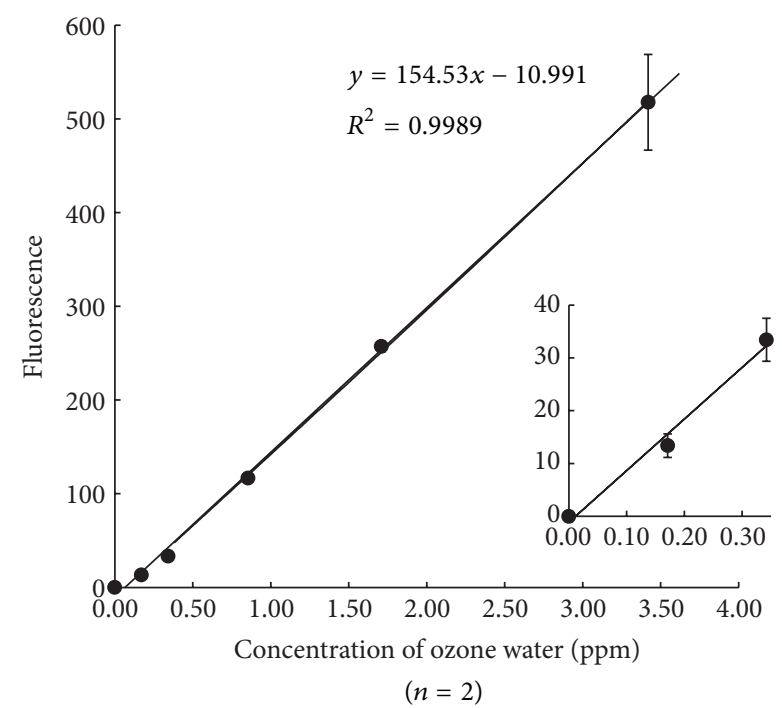

FIGURE 7: Standard curve for ozone.

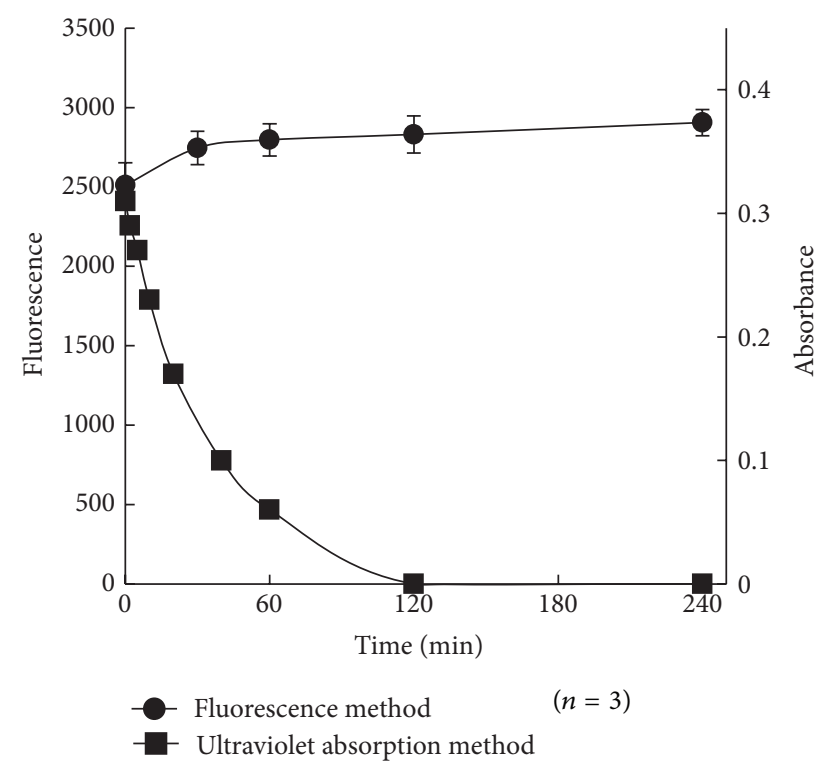

FIGURE 8: Stability of the reaction product from Probe 1 reacted with ozone (fluorescence method) and absorbance of ozone water (ultraviolet absorption method).

The specificity of this assay was also determined. Hydroxyl radical $(\mathrm{OH})$ from the Fenton reaction was used. Hydroxyl radical, $\mathrm{NaClO}$ (40 ppm), $\mathrm{O}_{2}^{-}$radical from xanthine oxidase, $\mathrm{NaNO}_{2}(40 \mathrm{ppm}), \mathrm{KNO}_{3}(40 \mathrm{ppm})$, nitric oxide from NOC-7, and hypoxanthine were also assessed. The following fluorescence intensities were obtained: tap water: $0.38 \%$, $\mathrm{NaClO}: 0.30 \%, \mathrm{OH}$ radical: $0.29 \%, \mathrm{O}_{2}{ }^{-}: 0.43 \%$, NO: $0.40 \%, \mathrm{NO}_{2}{ }^{-}: 0.36 \%, \mathrm{NO}_{3}^{-}: 0.38 \%$ when the radical fluorescence intensity of ozone water $(6.3 \mathrm{ppm})$ was $100 \%$ $(n=2)$. Therefore, Probe 1 has high specificity for ozone.

Finally, the stability of the product formed by the reaction of probe 1 with ozone was investigated by fluorescence intensity. After pyrrolidine solution was added and reacted for $5 \mathrm{~min}$ at room temperature, the fluorescence intensity after $0,30,60,120$, and $240 \mathrm{~min}$ was measured. No decrease in fluorescence intensity (mean of $n=2$ at each point) was observed. In contrast, the concentration of ozone in water measured using the ultraviolet absorption method decreased by half at $30 \mathrm{~min}$ after preparation of the ozone-containing water and completely disappeared after $120 \mathrm{~min}$, as shown in Figure 8. Therefore, ozone can be measured with high reproducibly using probe $\mathbf{1}$.

\section{Conclusion}

Probe 1 clearly reacted with ozone quantitatively and specifically and resulted in the formation of a stable fluorescent substance under the conditions described above. This assay is therefore useful for quantifying ozone in environmental science, biochemistry, and clinical chemistry by specifically detecting ozone, unlike conventional, nonspecific assays. This methodology may be useful in the quality control of ozone products and ozonizers.

\section{Conflict of Interests}

The authors declare that there is no conflict of interests regarding the publication of this paper.

\section{Acknowledgments}

The authors thank Professor Kazunori Koide and Dr. Michael P. Cook of University of Pittsburgh for kindly providing Probe 1 and their support.

\section{References}

[1] T. Le and S. Tao, "Intrinsic UV absorption spectrometry observed with a liquid core waveguide as a sensor technique for monitoring ozone in water," Analyst, vol. 136, no. 16, pp. 33353342, 2011.

[2] D. L. Flamm and S. A. Anderson, "Iodate formation and decomposition in iodometric analysis of ozone," Environmental Science and Technology, vol. 9, no. 7, pp. 660-663, 1975.

[3] G. Gordon and B. Bubnis, "Residual ozone measurement: indigo sensitivity coefficient adjustment," Ozone: Science \& Engineering, vol. 24, no. 1, pp. 17-28, 2002.

[4] H. Bader and J. Hoigne, "Determination of ozone in water by the indigo method: a submitted standard method ( Switzerland)," Ozone: Science \& Engineering, vol. 4, no. 4, pp. 169-176, 1982.

[5] Patent Application Publication no. H8-304334.

[6] A. L. Garner, C. M. St Croix, B. R. Pitt, G. D. Leikauf, S. Ando, and K. Koide, "Specific fluorogenic probes for ozone in biological and atmospheric samples," Nature Chemistry, vol. 1, pp. 316-321, 2009.

[7] G. Gordon, G. E. Pacey, W. J. Cooper, and R. G. Rice, "The chemical reactions of ozone and their role in developing improved analytical methods," Ozone: Science \& Engineering, vol. 10, no. 1, pp. 89-102, 1988.

[8] H. J. H. Fenton, "Oxidation of tartaric acid in the presence of iron," Journal of the Chemical Society, vol. 65, pp. 899-910, 1894. 
[9] E. Welles Kellogg and I. Fridovich, "Superoxide, hydrogen peroxide, and singlet oxygen in lipid peroxidation by a xanthine oxidase system," Journal of Biological Chemistry, vol. 250, no. 22, pp. 8812-8817, 1975.

[10] J. A. Hrabie, J. R. Klose, D. A. Wink, and L. K. Keefer, "New nitric oxide-releasing zwitterions derived from polyamines," Journal of Organic Chemistry, vol. 58, no. 6, pp. 1472-1476, 1993.

[11] J. Weiss, "Investigations on the radical $\mathrm{HO}_{2}$ in solution," Transactions of the Faraday Society, vol. 31, pp. 668-681, 1935.

[12] A. K. Leslie, D. Li, and K. Koide, "Amine-promoted $\beta$ elimination of a $\beta$-aryloxy aldehyde for fluorogenic chemodosimeters," Journal of Organic Chemistry, vol. 76, no. 16, pp. 6860-6865, 2011. 

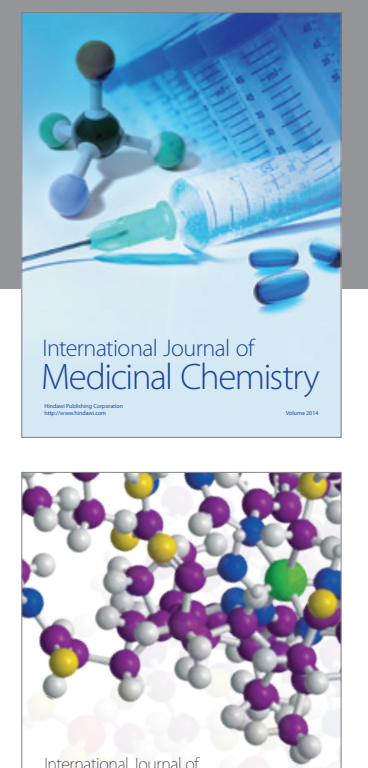

\section{Carbohydrate} Chemistry

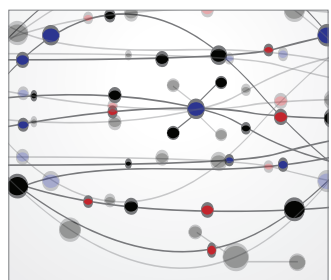

The Scientific World Journal
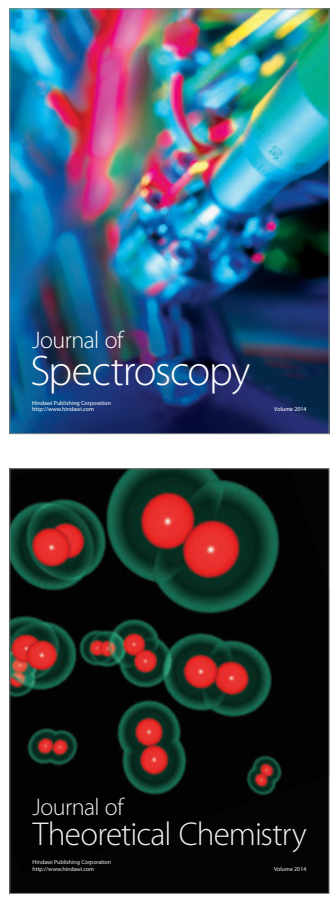
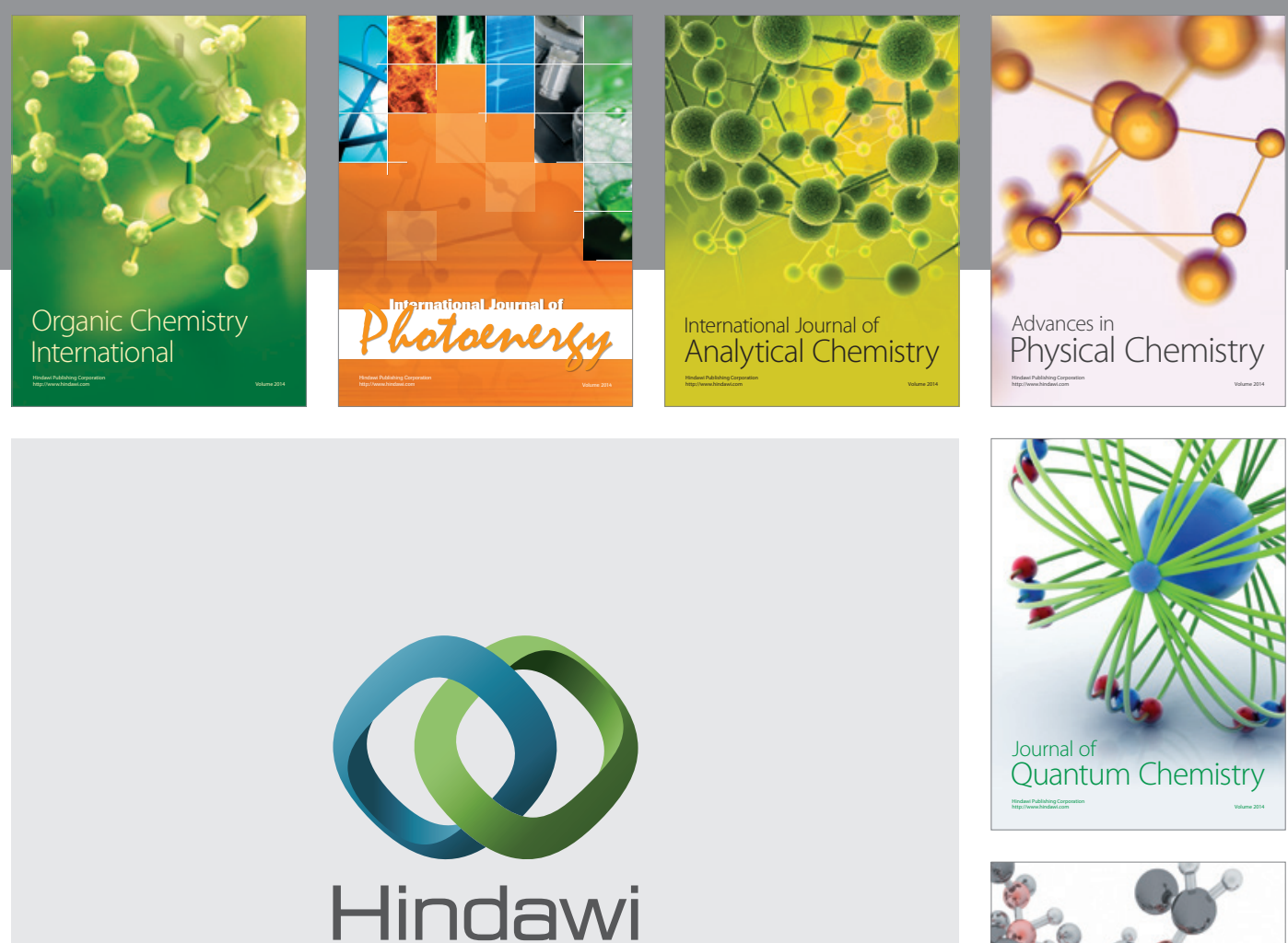

Submit your manuscripts at

http://www.hindawi.com

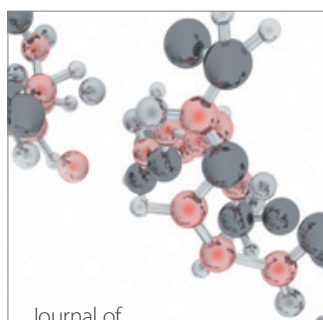

Analytical Methods

in Chemistry

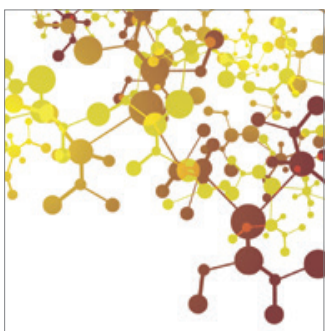

Journal of

Applied Chemistry

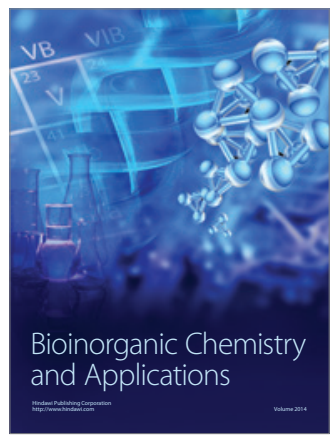

Inorganic Chemistry
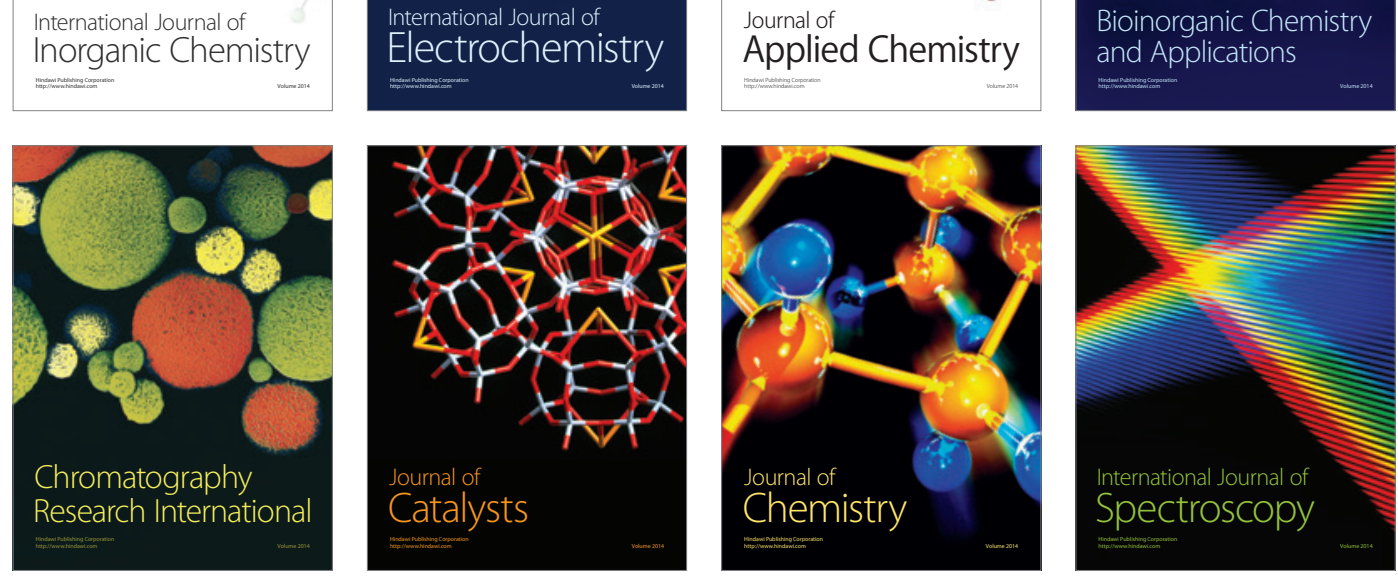